\title{
The Effect of Root Canal Irrigation with Combination of Sodium Hypo- chlorite and Chlorhexidine Gluconate on the Sealing Ability of Obturation Materials
}

\author{
Hamed Homayouni ${ }^{1}$, Nima Moradi Majd ${ }^{2}$, Heidar Zohrehei ${ }^{3,},{ }^{*}$, Behrad Mosavari ${ }^{4}$, Mamak Adel ${ }^{1}$, \\ Reyhaneh Dajmar ${ }^{1}$ and Ali Homayouni ${ }^{5}$
}

${ }^{I}$ Department of Endodontics, Dental School, Qazvin University of Medical Sciences, Qazvin, Iran

${ }^{2}$ Dental Research Laboratory, Howard University College of Dentistry, Washington DC, USA

${ }^{3}$ Dental Research Center, Shahid Beheshti University of Medical Sciences, Tehran, Iran

${ }^{4}$ Dental Carries Research Center, School of Dentistry, Qazvin University of Medical Sciences, Qazvin, Iran

${ }^{5}$ Dental Research Center Dentistry Research Institute, School of Dentistry, Tehran University of Medical Sciences, Tehran, Iran

\begin{abstract}
Objectives: The aim of this study was to evaluate the effect of the precipitate that was formed by combining Sodium Hypochlorite $(\mathrm{NaOCl})$ and Chlorhexidine Gluconate $(\mathrm{CHX})$ on the sealing ability of root canal obturation materials.

Materials and Methods: The fluid filtration method was conducted on a total of 100 roots. Samples were randomly divided into two control $(\mathrm{n}=5)$ and three experimental groups $(\mathrm{n}=30)$. The samples in group 1 were irrigated with $1.5 \mathrm{~mL}$ of $2.5 \% \mathrm{NaOCl}$, and then the smear layers of the teeth were removed by 17\% EDTA, while the specimens of group 2 were irrigated by $1.5 \mathrm{~mL}$ of $2.5 \% \mathrm{NaOCl}$ and $1.5 \mathrm{~mL}$ of $2 \% \mathrm{CHX}$; after the smear layer removal, a final flush with $1.5 \mathrm{~mL}$ of $2.5 \% \mathrm{NaOCl}$ was performed. The samples of group 3 were irrigated the same as group 1 but after the smear layer removal canals were irrigated again with $1.5 \mathrm{~mL}$ of $2.5 \% \mathrm{NaOCl}$ and then a final flush with $1.5 \mathrm{~mL}$ of $2 \% \mathrm{CHX}$ was performed. Teeth were obturated with gutta-percha and AH26 sealer and after seven days, microleakage was evaluated by the fluid filtration technique. The results were analyzed by the ANOVA and Tukey's test.

Results: The samples in group 3 had significantly greater microleakage compared to teeth in group 1,2 ( $\mathrm{p}<0.05)$, and the specimens in group 1 showed significantly less amount of microleakage than samples in group 2, $3(\mathrm{P}<0.05)$.

Conclusion: The presence of the precipitate that is formed due to interaction between $\mathrm{NaOCl}$ and $\mathrm{CHX}$ has negative effect on the sealing ability of gutta-percha and AH26 sealer.
\end{abstract}

Keywords: Chlorhexidine gluconate, Fluid filtration technique, Microleakage, Para-chloroaniline, Sodium hypochlorite.

\section{INTRODUCTION}

It has been shown that microorganisms and their metabolites are the main etiology for the pulp and periapical diseases [1]. Therefore, the success of endodontic treatment critically depends on the degree of microbial control and the quality of treatment [2].

Different intracanal irrigants have been used to minimize the bacterial load in the infected root canals [3]. Sodium hypochlorite $(\mathrm{NaOCl})$ is the most common irrigation solution used during root canal treatments [4]. It is an excellent

*Address correspondence to this author at the Dental Research Center, Shahid Beheshti University of Medical Sciences, Evin, Tehran, Zip code: 1983963113, Iran; Tel: +98 21 22413897; Fax: +98 21 22427753;

E-mail: h_zohrehei@yahoo.com non-specific proteolytic and antimicrobial agent [4]; but it is a toxic agent and serious mishap can result from its inappropriate use [5]. In addition, some controversies do exist with regard to sodium hypochlorite's antimicrobial activity at lower concentrations, which are advocated as an attempt to reduce its toxic effects [6-8].

The other endodontic irrigation solution that has been used to disinfect root canals is Chlorhexidine gluconate (CHX) [9]. It has been shown that CHX has potent and substantive antimicrobial activity against some resistant bacteria such as Enterococcus faecalis [10-12].

Although, CHX is an acceptable antibacterial agent, it is not able to dissolve the remaining pulp tissues during root canal preparation [9]. Furthermore, it has been indicated that the use of combination of $\mathrm{NaOCl}$ and $\mathrm{CHX}$ during root canal treatments reduces the bacterial load more effectively, and 
Table 1. Sequences of using ProTaper rotary instruments according to manufacturer's recommendations.

\begin{tabular}{|c|c|}
\hline File Type & Length \\
\hline \hline $\mathrm{S}_{1}$ & $1 / 3$ to $2 / 3$ coronal \\
\hline $\mathrm{S}_{\mathrm{X}}$ & $2 / 3$ coronal \\
\hline $\mathrm{S}_{1}, \mathrm{~S}_{2}, \mathrm{~F}_{1}, \mathrm{~F}_{2}, \mathrm{~F}_{3}, \mathrm{~F}_{4}$ & Working length \\
\hline
\end{tabular}

Table 2. Mean (SD) leakage values for three experimental groups.

\begin{tabular}{|c|c|}
\hline Groups & Mean (SD) Leakage Values \\
\hline \hline $\begin{array}{c}\text { Group1 (irrigation: } \mathrm{NaOCl} \text {, final } \\
\text { flush: } \mathrm{NaOCl})\end{array}$ & $0.049(0.032)$ \\
\hline $\begin{array}{c}\text { Group2 (irrigation: } \mathrm{NaOCl}+ \\
\mathrm{CHX} \text {, final flush: } \mathrm{NaOCl})\end{array}$ & $0.076(0.028)$ \\
\hline $\begin{array}{c}\text { Group3 (irrigation: } \mathrm{NaOCl}, \text { final } \\
\text { flush: } \mathrm{NaOCl}+\mathrm{CHX})\end{array}$ & $0.106(0.054)$ \\
\hline
\end{tabular}

this reduction is significant compared to use of $\mathrm{NaOCl}$ alone [13].

On the other hand, it has been shown that the combination of $\mathrm{NaOCl}$ and $\mathrm{CHX}$ leads to the formation of a precipitate [14]. The presence of para-chloroaniline (PCA) in the precipitate has been demonstrated by several studies [1517]. There is a concern regarding the noxious effects of this precipitate [17]; such as its cytotoxicity, causing the microleakage and so on.

Since it seems unlikely that a noticeable amount of this combination could be extruded from the apical foramen, its negative influence on sealing ability of the obturation material is more critical than its probable cytotoxic effect.

The aim of this study was to evaluate the effect of the precipitate that was formed by combining $\mathrm{NaOCl}$ and $\mathrm{CHX}$ on the sealing ability of root canal obturation materials.

\section{MATERIALS AND METHODS}

This study was approved by the Ethics Committee of Qazvin University of Medical Sciences, Qazvin, Iran. A total of 100 maxillary anterior teeth were selected. In order to disinfect the extracted teeth, they were stored in $5.25 \%$ sodium hypochlorite for an hour and then placed in normal saline before the experiment. For standardization of all specimens to a length of $13 \pm 1 \mathrm{~mm}$, the crowns of the teeth were sliced using a diamond disc (Jota, Germany) attached to the laboratorial handpiece. Afterwards, \#10 K-files (Maillefer,Dentsply, Tulsa, Switzerland) were inserted into the canals, until the instrument tips were visible at the apical foramen, in so doing the real root canals' length were determined. Working length was established $1.0 \mathrm{~mm}$ shorter than real root canal length.

The specimens were prepared, by the ProTaper system (Dentsply Maillefer, Ballaigues, Switzerland) according to the manufacturer's instructions (Table 1), using a low-torque motor with a constant speed of $300 \mathrm{rpm}$ (ATR Tecnika, Advanced Technology Research, Pistoia, Italy). Patency was obtained with a K-type file size \#15. The prepared samples were randomly divided into three experimental Groups $(n=30)$ and two negative and positive control groups $(n=5)$.

In group 1, canals were irrigated with $1.5 \mathrm{~mL}$ of $2.5 \%$ $\mathrm{NaOCl}$ (Kimia Tehran Acid, Tehran, Iran). After root canal instrumentation, in order to remove the smear layer, $3.0 \mathrm{~mL}$ of $17 \%$ EDTA (Ariadent, Tehran, Iran) were introduced and allowed to remain in the canals for 3 minutes. Next, a final flush with $1.5 \mathrm{~mL}$ of $2.5 \% \mathrm{NaOCl}$ was performed.

In group 2, canals were irrigated with $1.5 \mathrm{~mL}$ of $2.5 \%$ $\mathrm{NaOCl}$ and $1.5 \mathrm{~mL}$ of $2 \% \mathrm{CHX}$ (Prevest Denpro, Jammu, India). Then, smear layers were removed identical to group 1. Afterwards, a final flush with $1.5 \mathrm{~mL}$ of $2.5 \% \mathrm{NaOCl}$ was performed.

In group 3, canals were irrigated the same as group 1; but after the smear layer removal, canals were irrigated again with $1.5 \mathrm{~mL}$ of $2.5 \% \mathrm{NaOCl}$ and then a final flush with 1.5 $\mathrm{mL}$ of $2 \% \mathrm{CHX}$ was performed.

All root canals have been dried with paper points (Ariadent, Tehran, Iran), and then have been obturated using lateral compaction technique with gutta-percha (Gapadent Co., LTD, Korea) and AH26 sealer (DeTrey, Dentsply, Konstanz, Germany). Next, they were stored at $37^{\circ} \mathrm{C}$ in $95 \%$ humidity for 24 hours. After this period of time, the external root surfaces of the specimens were covered with three coats of nail polish and one layer of cyanoacrylate glue (Interlock Co., LTD, Japan) except for an area of $2.0 \mathrm{~mm}$ around the root apex.

In control groups, samples were prepared and irrigated the same as group 1, but in positive control group no obturation was performed, while teeth in negative control group were obturated identical to the samples of experimental groups, root surfaces of the specimens of negative control group were completely covered with three coats of nail polish and one layer of cyanoacrylate glue.

Seven days after obturation of root canals, leakage was evaluated by the fluid filtration technique employing a pressure equivalent to 0.5 atmosphere, as described in previous studies $[18,19]$. Four measurements were recorded for each tooth at 2-minutes intervals over a period of 8 minutes.

The amount of leakage was expressed as $\mu \mathrm{L} / \mathrm{min} / \mathrm{cmH}_{2} \mathrm{O}$. Results were analyzed by the ANOVA and Tukey's test. The significance level was set at $5 \%$ for all tests.

\section{RESULTS}

The negative control group did not show any apical leakage, while, the positive control group showed the maximum amount of leakage. A statistical significant difference $(p<0.05)$ was observed among the amounts of microleakage in samples of three experimental groups (Table 2).

The samples in group 3 had significantly greater microleakage compared to teeth in group $1,2(\mathrm{p}<0.05)$, and the specimens in group 1 showed significantly less amount of microleakage than samples in group 2, $3(\mathrm{P}<0.05)$. 


\section{DISCUSSION}

It has been shown that the outcome of endodontic treatment depends on elimination of microorganisms from the root canal system [2]; on the other hand, complete removal of root canal bacteria is a very difficult challenge [20].

As mentioned before, it has been demonstrated that the use of combination of $\mathrm{NaOCl}$ and $\mathrm{CHX}$ during root canal treatments reduces the bacterial load more effectively [13]; but we know that the interaction between these two irrigants leads to the formation of a precipitate [14], and this is a considerable concern for the practitioners.

Schilder stated that the final objective of endodontic procedure is the total obturation of the root canal space [21]. Therefore, the probable negative impacts of the abovementioned precipitate on the sealing ability of the obturation materials could be a serious obstacle to achieve this final objective.

To determine the effect of different irrigants on the sealing ability of obturation materials, various methods have been suggested: polymicrobial leakage, linear dye leakage, fluid filtration, diaphanization, radioisotope labeling and the electrochemical method [22].

In this study, we employed fluid filtration technique; because using this method, quantitative analysis of endodontic microleakage is achievable [22]. In addition, since very small volume can be recorded in this technique, the results are very accurate [18].

In order to obturate the root canal systems, gutta-percha and AH26 sealer have been used; because these obturation materials are commonly used in the endodontic procedures [23].

In this study, we intended to assess the effect of the precipitate that is formed due to interaction between $\mathrm{NaOCl}$ and $\mathrm{CHX}$ on the sealing ability of obturation materials. That is why we did not try to prevent this precipitate's formation using intermediate and/or final flushes with normal saline or distilled water, although a previous study has shown that using saline and distilled water as intermediate flushes cannot completely prevent formation of this insoluble neutral salt [24].

In the present study, the least amount of microleakage was observed in the specimens of group 1 where no $\mathrm{CHX}$ had been used during root canal irrigation. Therefore, it is obvious that no precipitate had been formed in the root canal system of this group's samples. Conversely, the teeth in group 3 showed the greatest amount of microleakage.

As described before, teeth in group 3 have been irrigated by $\mathrm{NaOCl}$ during root canal instrumentation. Afterwards, smear layer was removed, and a final flush with $1.5 \mathrm{~mL}$ of $\mathrm{NaOCl}$ followed by $1.5 \mathrm{~mL}$ of $\mathrm{CHX}$ was performed. Thus, it is clear that the formation of the precipitate occurred at the end of the canal irrigation, and there was no chance to wash it out before canal obturation. On the contrary, in the samples of group 2, $\mathrm{NaOCl}$ and $\mathrm{CHX}$ were used to irrigate the root canals; but after smear layer removal a final flush with $1.5 \mathrm{~mL}$ of $\mathrm{NaOCl}$ was performed. So, it is possible that some part of the precipitate which had been formed during canal instrumentation were removed by the final flush.
Therefore, it can be assumed that the samples of group 3 had the highest amount of residual precipitate before starting root canal obturation. Consequently, they showed the greatest amount of microleakage.

\section{CONCLUSION}

Within the limitations of the present in vitro study, it can be concluded that the presence of the precipitate that is formed due to interaction between $\mathrm{NaOCl}$ and $\mathrm{CHX}$ has negative effect on the sealing ability of gutta-percha and AH26 sealer.

\section{CONFLICT OF INTEREST}

The authors confirm that this article content has no conflict of interest.

\section{ACKNOWLEDGEMENTS}

The authors wish to thank Mrs. Shiva Esmaili for her advice as a statistician in this study.

\section{REFERENCES}

[1] Kakehashi S, Stanley HR, Fitzgerald RJ. The effects of surgical exposures of dental pulps in germ-free and conventional laboratory rats. Oral Surg Oral Med Oral Pathol1965; 20: 340-9.

[2] Sjögren U, Figdor D, Persson S, Sundqvist G. Influence of infection at the time of root filling on the outcome of endodontic treatment of teeth with apical periodontitis. Int Endod J 1997; 30(5): 297-306.

[3] Fedorowicz Z, Nasser M, Sequeira-Byron P, de Souza RF, Carter $\mathrm{B}, \mathrm{Heft}$ M. Irrigants for non-surgical root canal treatment in mature permanent teeth. Cochrane Database Syst Rev 2012; 9: CD008948.

[4] Mohammadi Z. Sodium hypochlorite in endodontics: an update review. Int Dent J 2008; 58(6): 329-41.

[5] Goswami M, Chhabra N, Kumar G, Verma M, Chhabra A. Sodium hypochlorite dental accidents. Paediatr Int Child Health 2012; p.13.

[6] Gomes BP, Ferraz CC, Vianna ME, Berber VB, Teixeira FB, Souza-Filho FJ. In vitro antimicrobial activity of several concentrations of sodium hypochlorite and chlorhexidine gluconate in the elimination of Enterococcus faecalis. Int Endod J 2001; 34: 424-8.

[7] Vianna ME, Gomes BP, Berber VB, Zaia AA, Ferraz CC, de Souza-Filho FJ. In vitro evaluation of the antimicrobial activity of chlorhexidine and sodium hypochlorite. Oral Surg Oral Med Oral Pathol Oral Radiol Endod 2004; 97: 79-84.

[8] Carson KR, Goodell GG, McClanahan SB. Comparison of the antimicrobial activity of six irrigants on primary endodontic pathogens. J Endod 2005; 31:471-3.

[9] Basrani B, Lemonie C. Chlorhexidine gluconate. Aust Endod J 2005; 31(2): 48-52.

[10] Leonardo MR, Tanomaru Filho M, Silva LA, et al. In vivo antimicrobial activity of $2 \%$ chlorhexidine used as a root canal irrigating solution. J Endod 1999; 25:167-71.

[11] Ferraz CC, Gomes BP, Zaia AA, Teixeira FB, Souza-Filho FJ. In vitro assessment of the antimicrobial action and the mechanical ability of chlorhexidine gel as an endodontic irrigant. J Endod 2001; 27: 452-5.

[12] Wang CS, Arnold RR, Trope M, Teixeira FB. Clinical efficiency of $2 \%$ chlorhexidine gel in reducing intracanal bacteria. $\mathrm{J}$ Endod 2007; 33:1283-9.

[13] Kuruvilla JR, Kamath MP. Antimicrobial activity of 2.5\% sodium hypochlorite and $0.2 \%$ chlorhexidine gluconate separately and combined, as endodontic irrigants. J Endod 1998; 24: 472-6.

[14] Basrani BR, Manek S, Sodhi RN, Fillery E, Manzur A. Interaction between sodium hypochlorite and chlorhexidine gluconate. J Endod 2007; 33: 966-9. 
[15] Basrani BR, Manek S, Fillery E. Using diazotization to characterize the effect of heat or sodium hypochlorite on $2.0 \%$ chlorhexidine. $\mathrm{J}$ Endod 2009; 35:1296-9.

[16] Basrani BR, Manek S, Mathers D, Fillery E, Sodhi RN. Determination of 4-chloroaniline and its derivatives formed in the interaction of sodium hypochlorite and chlorhexidine by using gas chromatography. J Endod 2010; 36(2): 312-4.

[17] Vivacqua-Gomes N, Ferraz CC, Gomes BP, Zaia AA, Teixeira FB, Souza-Filho FJ. Influence of irrigants on the coronal microleakage of laterally condensed gutta-percha root fillings. Int Endod J 2002; 35(9): 791-5.

[18] Wu MK, Wesselink PR. Endodontic leakage studies reconsidered. Part I. Methodology, application and relevance. Int Endod J 1993; 26: 37-43.

[19] Moradi S, Naghavi N, Rohani E, Javidi M. Evaluation of microleakage following application of a dentin bonding agent as root canal sealer in the presence or absence of smear layer. J Oral Sci 2009; 51(2): 207-13.

[20] Ohara P, Torabinejad M, Kettering JD. Antibacterial effects of various endodontic irrigants on selected anaerobic bacteria. Endod Dent Traumatol 1993; 9(3): 95-100.

[21] Schilder H. Filling the root canal in three dimensions. Dent Clin North Am 1967; 723-44.

[22] Veríssimo DM, do Vale MS. Methodologies for assessment of apical and coronal leakage of endodontic filling materials: a critical review. J Oral Sci 2006; 48: 93-8.

[23] Yilmaz Z, Tuncel B, Ozdemir HO, Serper A. Microleakage evaluation of roots filled with different obturation techniques and sealers. Oral Surg Oral Med Oral Pathol Oral Radiol Endod 2009; 108(1): 124-8.

[24] Krishnamurthy S, Sudhakaran S. Evaluation and prevention of the precipitate formed on interaction between sodium hypochlorite and chlorhexidine. J Endod 2010; 36(7): 1154-7.

Received: July 16, 2014

(C) Homayouni et al.; Licensee Bentham Open.

This is an open access article licensed under the terms of the Creative Commons Attribution Non-Commercial License (http://creativecommons.org/licenses/by-nc/3.0/) which permits unrestricted, non-commercial use, distribution and reproduction in any medium, provided the work is properly cited. 